\title{
Coconut oil supplementation reduces blood pressure and oxidative stress in spontaneously hypertensive rats
}

\author{
Naiane Ferraz Bandeira Alves, Naiane Alves, Suênia Porpino, Matheus Monteiro, Thyago Queiroz, \\ Karen Montenegro, Valdir Braga \\ From 5th Congress of the Brazilian Biotechnology Society (SBBIOTEC) \\ Florianópolis, Brazil. 10-14 November 2013
}

\section{Background}

Oxidative stress has been implicated in the pathogenesis of hypertension and antioxidant compounds have been used in the prevention and treatment of this disease. In this context, coconut oil (CO) was found to have antioxidant property due to its high polyphenol content. In this study, we investigated the effects caused by chronic treatment with $\mathrm{CO}$ on mean arterial pressure (MAP), heart rate (HR), and lipid peroxidation in spontaneously hypertensive rats (SHR).

\section{Methods}

SHR and their controls (Wistar Kyoto, WKY) were orally treated with coconut oil $(2 \mathrm{ml} /$ day $)$ or saline for thirty days. Cardiovascular parameters were evaluated 24 hours after the end of the thirtieth day. Serum oxidative stress was measured by tiobarbituric acid reactive species assay (TBARS).

\section{Results and conclusions}

The administration of $\mathrm{CO}$ was able to reduced the MAP of SHR compared to SHR treated with saline $(146 \pm 11$ $\mathrm{n}=5$ vs. $174 \pm 6 \mathrm{n}=8 \mathrm{mmHg}$, respectively, $\mathrm{p}<0.05)$. On the other hand, treatment with CO had no effect on MAP of WKY compared with WKY treated with saline $(136 \pm 3 \mathrm{n}=6$ vs. $113 \pm 1 \mathrm{mmHg} \mathrm{n}=8$, respectively, $\mathrm{p}<0.05)$. In addition, $\mathrm{CO}$ supplementation reduced lipid peroxidation in the SHR group compared to SHR + saline $(13.7 \pm 2$ vs. $27.5 \pm 5 \mathrm{nmol} / \mathrm{g} \mathrm{n}=7$, respectively, $\mathrm{p}<0.05)$ and also reduced in WKY compared with WKY treated with saline $(11.5 \pm 1$ vs. $21.9 \pm 2 \mathrm{nmol} / \mathrm{g} \mathrm{n}=7$ respectively, $\mathrm{p}<0.05)$. We concluded that treatment with coconut oil

Universidade Federal Da Paraíba, João Pessoa, PB, Brazi
( $2 \mathrm{ml} /$ day) for thirty days reduces the blood pressure and oxidative stress in hypertensive rats.

\section{Acknowledgements}

Biotechnology Center - Universidade Federal da Paraíba

Published: 1 October 2014

\section{References}

1. Dauqan E, Sani HA, Abdullah A, Kasim ZM: Effect of four different vegetable oils (red palm olein, palm olein, corn oil, coconut oil) on antioxidant enzymes activity of rat liver. Pakistan Journaf of Biological Sciences 2011, 14(6):399-403.

2. DebMandal M, Mandal S: Coconut (Cocos nucifera L.: Arecaceae): in health promotion and disease prevention. Asian Pacific Journal of Tropical Medicine 2011, 4(3):241-247, doi: 10.1016/S1995-7645(11)60078-3.

\section{doi:10.1186/1753-6561-8-S4-P68}

Cite this article as: Bandeira Alves et al:: Coconut oil supplementation reduces blood pressure and oxidative stress in spontaneously hypertensive rats. BMC Proceedings 2014 8(Suppl 4):P68.
Submit your next manuscript to BioMed Central and take full advantage of:

- Convenient online submission

- Thorough peer review

- No space constraints or color figure charges

- Immediate publication on acceptance

- Inclusion in PubMed, CAS, Scopus and Google Scholar

- Research which is freely available for redistribution
() Biomed Central 